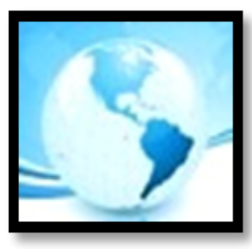

MALAYSIAN ONLINE JOURNAL OF

EDUCATIONAL MANAGEMENT

(MOJEM)

JANUARY 2016, VOLUME 4, ISSUE 1, 1 - 16

E-ISSN NO: $2289-4489$

https://doi.org/10.22452/mojem.vol4no1.1

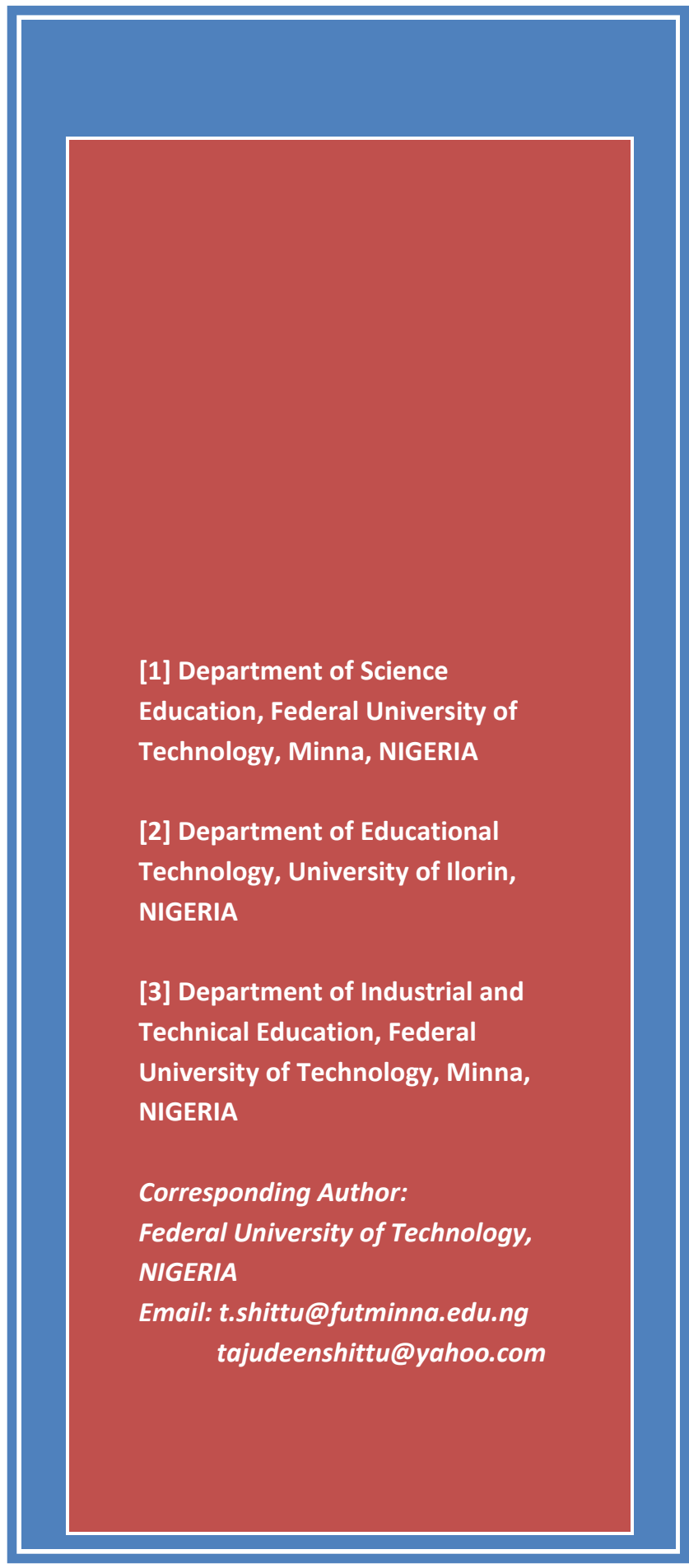

\section{ACCEPTANCE OF INFORMATION TECHNOLOGY FOR TEACHING IN NIGERIAN VOCATIONAL AND TECHNICAL EDUCATION: A CONFIRMATORY FACTOR ANALYSIS}

Shittu, Ahmed Tajudeen ${ }^{1}$ (PhD) ,Fakomogbon, Micheal $A^{2}(P h D)$, Gambari, Amosa Isiaka ${ }^{1}$ (PhD) \& Owodunni, A. Samuel ${ }^{3}$ (PhD)

\begin{abstract}
This study was conducted to determine the correlation among four factors influencing acceptance of IT for teaching. The study attempted to re-examine the indicators of technology acceptance theory through confirmatory factor analysis. Perceived Usefulness (PU) and Perceived Ease of Use (PEOU) of the Technology Acceptance Model was the theoretical base of the study. Construct of Computer Self-Efficacy and Facilitating Condition was tested along PU and PEOU. The participants of the study consist of one hundred and twenty-three (123) technical and vocational education teachers in selected secondary schools in llorin West, East and South of Kwara State, Nigeria. To ascertain the correlation among the four constructs of the study, a correlation model was proposed, and statistical analysis was conducted. The instrument reliability was ascertained. Similarly, convergent and discriminant validity was conducted through factor analysis with SPSS 16. A confirmatory factor analysis was carried out with Structural Equation Modeling. The data were equally subjected to t-test analysis to identify if vocational and technical education teacher use of IT for teaching differed by gender. The result showed that there is no difference by gender in IT use for teaching. Moreover, the results showeda significant correlation among all the factors in influencing acceptance of IT for teaching. The study has implications for all stakeholders in preventing problems associated with IT acceptance for teaching. The study also serves as a template for understanding acceptance of IT for teaching in the Nigerian school system.
\end{abstract}

Keywords: Technology Acceptance Model, teachers, Self-efficacy, Vocational and Technical Education, Nigeria 


\section{INTRODUCTION}

The value attached to acquisition of technical and vocational education cannot be over-emphasized because of its importance to the technological advancement of every society. This explains the justification for including the subject and courses in primary, secondary and tertiary institutions in the Nigerian school system. The goal of technical and vocational education as enshrined in the National Policy on Education $(2004,2013)$ include among others, to provide trained manpower in the applied sciences, technology and business, particularly in craft, and advanced craft at technical levels; provide the technical knowledge and vocational skills necessary for agriculture, commercial and economic development; and to give training and impart the necessary skills for economic selfreliance. In alignment with these goals, vocational and technical education will be used to achieve the following: full employment for the youth; technological advancement and economic development; international economic and political independence as well as reduction in crime and social vices.

Despite the relevance of the subject, implementing its curriculum in Nigerian secondary schools has become a source of concern in recent years, because of the Information Technology (IT) skill needed to accomplish the teaching task of this important subject effectively and efficiently. The issue of paradigm shift in teaching and learning process required by deployment of IT for teaching is attracting attention of educational researchers. Acquisition of IT knowledge by teachers in their respective subject areas is emphasized because they are expected to deploy IT for school curriculum implementation.

In education today, increased emphasis is placed on using IT for facilitating knowledge to the students, because learners are required to obtain IT knowledge in their course of study. This places additional responsibility on teachers to use IT to turn students into lifelong learners and ultimately make them relevant in today's world of work.

The present information explosion age demands that teachers at all levels integrate IT in the learning environment. How various factors influence teachers' decision and their IT usein the classroom are of great importance to many researchers and a government burdened with providing the necessary resources for attaining educational goals. As a result, researchers in IT-related fields and education have preoccupied themselves with understanding some of the intricacies surrounding IT acceptance in the teaching and learning processes.

According to Tarcan, Varol, Kantarci, and Firlar (2012) the importance of IT in education has made teacher's acceptance of IT in the teaching and learning environment a critical issue in the contemporary educational setting. This is because individual acceptance is an important factor determining the success or failure of a computer system project (Davis, 1989). Thus, teachers are the major determinant of effective IT use in teaching and learning. In the Nigerian educational system, the government has realized the relevance of IT in education and thus intensified efforts to deliver the needed resources for effective teaching in our secondary school system. Since resource availability is not the only determinant of usage, this study therefore, tries to understand some of the factors influencing teachers' decision to deploy IT for teaching in some selected secondary school in llorin, Nigeria. 


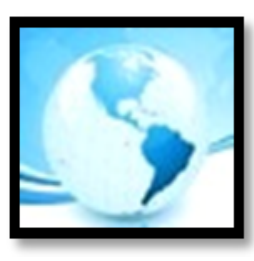

\section{MALAYSIAN ONLINE JOURNAL OF EDUCATIONAL MANAGEMENT (MOJEM)}

\section{The Need for the Study}

The need to understand factors affecting teachers' decision to accept IT use in teaching and learning has is important for realizing the educational goals in the contemporary world. Several studies have reported how user acceptance affects the decision to deploy innovations for teaching. According to Myers and Halpin (2002) as well as Abedalaziz, Jamaludin, and Leng (2013) teacher acceptance of IT is a major predictor of present and continuous classroom acceptance and usage. Li (2002) pointed out that a wide range of factors have been found to affect IT acceptance. The variations in the factors so far identified by researchers have been attributed to differences in context of study, sample population, teaching experience, field of study, and type of research. Though there appears to be a general consistency in some of the findings, yet research on acceptance seem to be inconclusive, especial yon the relationship that exists among the variables and constructs identified as predictors to acceptance of IT in teaching and learning. It is believed that the present study will serve as a template for further understanding of determinant of IT usage in the present population of the study and by extension serves as a foundation for understanding teachers' acceptance of IT in Nigeria.

The factors examined in this study are perceived usefulness and perceived ease of use of IT. Other factors include self-efficacy and skills of teachers in using IT, facilitating condition and use of IT tools. The study will look into the relationship existing among these variables in order to understand holistically how these factors relate in influencing the decision to use IT for teaching by vocational and technical education teachers.

\section{THEORETICAL FRAMEWORK}

The theoretical framework of the study is based on Davis's Technology Acceptance Model (TAM). Davis (1986) theory had received attention of researchers in the last decade. TAM was developed from the Theory of Reasoned Action (TRA) by Fishbein and Ajzen (1975). In TRA, attitudes which are influenced by individual belief were attributed to form behavioral intention and consequently trigger actual behavior. This proposition of the causal sequence of belief-attitude-intention-behavior to understand the determinant of IT acceptance and use in the TRA formed the basis for the Davis (1986) technology acceptance model. The original TAM as proposed by Davis posited that users' acceptance of information system is a function of perceived usefulness (PU) and perceived ease of use (PEOU) of the IT, and that the two constructs PU and PEOU determine behavioral intention and actual use of information systems.

Davis (1986) defined perceived usefulness as "the degree to which a person believes that using a particular system would enhance his or her job performance". On the other hand perceived ease of use is defined as the degree to which a person believes that using a particular system will be free of effort. Many studies have revealed that perceived usefulness and perceived ease of use are the major determinants of attitude toward IT use (Venkateh \& Davis, 1996). Empirical study of Al-Haderi (2013) had earlier shown that perceived usefulness has a stronger impact on usage than ease of use. In a similar study on IT use among student teachers, it was reported that perceived usefulness of computer technology had a direct significant effect on student teachers' intention to use IT in teaching (Ma, Anderson, \& Streith, 2005). The study also stated that the student teacher subjective norm did not have any direct or indirect effect on intention to use information technology. Determinant power of PU and PEOU on intention of users has been tested in many studies (Hair, Tatham, \& Black, 1998; Hendricson, Massey, \&Carron, 


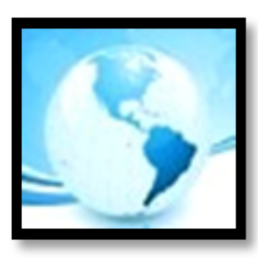

\section{MALAYSIAN ONLINE JOURNAL OF EDUCATIONAL MANAGEMENT (MOJEM)}

1993) and the result of some of the studies suggested that TAM is a parsimonious theory, and that its two constructs have strong predictive power.

\section{Self-Efficacy}

Bandura (1986) defined self-efficacy as the belief in one's capability to perform a specific task. Bandura further stated that the focus was not on the actual skills but the judgment of individuals on what they possess. If individuals perceive themselves as being capable of performing a certain task, they are said to have high selfefficacy. Thus, in the computer use situation, computer self-efficacy refers to a decision of one's potential to use a computer (Stylianou \& Jackson, 2007). According to Teo and Koh (2010) as stated in Zhao and Frank (2003) greater percentage of teachers are generally willing to deploy technology into their practice of teaching, although adoption may be slow or below expectation (Selwyn,2007).Al-Haderi (2013) provided evidence showing the significant influences of Computer Self-Efficacy (CSE) on outcome expectation and use of information system. In another study, Wu, Chang and Guo (2008) found a statistical relationship between teachers' CSE and intention to use IT in teaching. Also, Agarwal and Karahanna (2000) reported that CSE was a key antecedent of perceived ease of use.

Research findings also reported that work environment in terms of facilitating condition and teachers' attitude toward computer use may determine how teachers use technology for teaching (Ertner, 2005; Teo, 2008, 2010). Zhao and Cziko (2001) also showed that teachers' perceived ability to use technology greatly influenced technology use. This implies that teachers' belief about their competence to use information systems is an important factor in determining their response to IT integration for teaching and learning (Selwyn, Dawes, \& Mercer, 2001). In a study conducted by Yusuf (2005) on teachers' self-efficacy on computer use in Nigeria secondary schools, the result revealed that most teachers in the secondary school lack basic skill in using IT for teaching. Taking into consideration the time elapsed since the study of Yusuf and the government commitment in recent time in making IT use a medium of instruction in the Nigeria secondary school system, this study therefore becomes imperative in order to understand teacher self-efficacy along other related factors to clarify the relationship among these factors as they influence IT use in selected secondary schools in Ilorin, Nigeria.

\section{Facilitating Condition}

Facilitating Condition (FC) is the extent to which a person believes that an organization supports and provides technical existing infrastructure to promote the use of a system. According to Tarcan et al. (2012) FC in the technology friendly environment encourages technology use and makes a job easy to perform. FC in this context includes factors such as training, education, symposium, administrative and technical support provided to encourage technology acceptance (Groove \& Zenel, 2005.Some studies suggested availability of resources, level of knowledge to use technology, and availability of help resolve technological problems as facilitating condition .Venkatesh (2000) reported some of the hindrances to technology acceptance for teaching to include the following reasons: lack of access to computers, inadequate number of computers, lack of training programs, education and technical support. 


\section{Purpose of the Study}

The purpose of this study therefore, is to conduct a confirmatory factor analysis on factors relating to IT acceptance among vocational studies teachers in some selected secondary schools in Kwara state. In order to conduct the study, a proposed model in (Figure 1) was specified in order to understand the correlation existing among the factors tested in the study.

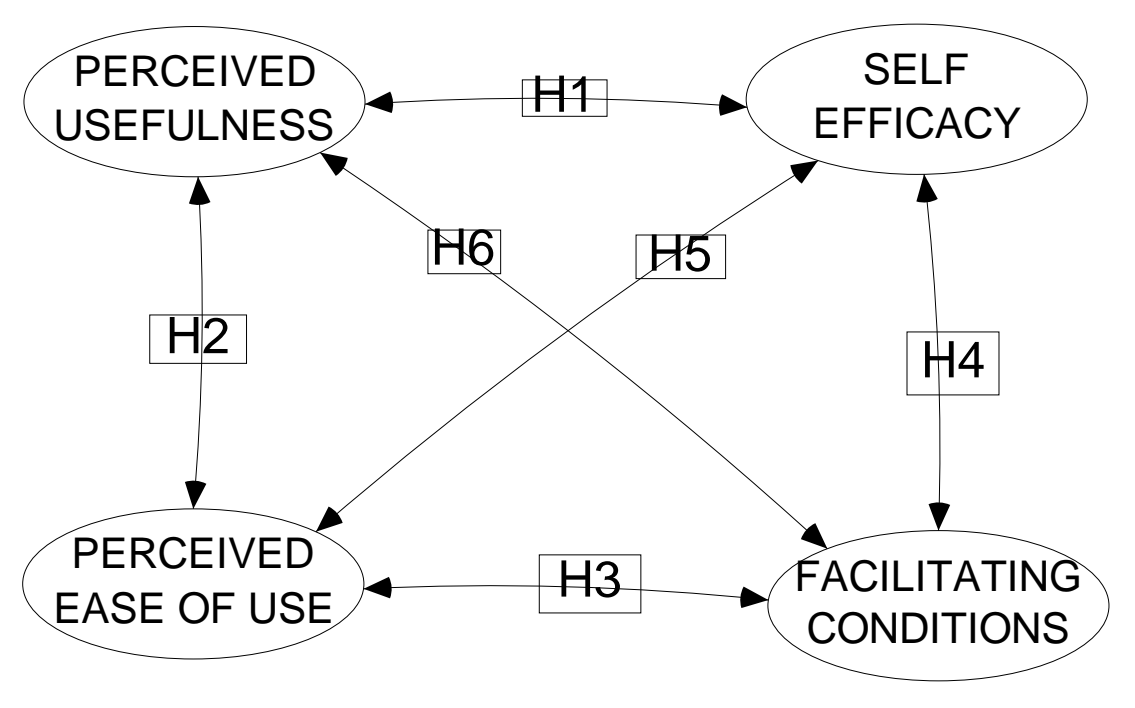

Figure 1.Proposed model of the study.

Based on the proposed model, the following hypotheses are formulated.

H1: There is a strong correlation between perceived usefulness and self-efficacy on the use of Information technology by the teacher

H2: There is a strong correlation between perceived usefulness and perceived ease of use on the use of Information technology by the teacher

H3: There is a strong correlation between perceived ease of use and facilitating condition on the use of Information technology by the teacher

H4: There is a strong correlation between facilitating conditions and self-efficacy on the use of Information technology by the teacher

H5: There is a strong correlation between perceived ease of use and self-efficacy on the use of Information technology by the teacher

H6: There is a strong correlation between perceived usefulness and facilitating condition on the use of Information technology by the teacher 


\section{Research Design}

The study involves a quantitative research design aimed at understanding determinants of IT usage among vocational and technical education teachers in llorin, Nigeria. The participants of the study were technical and vocational subject teachers. A total of two hundred(200) questionnaires were administered and one hundred and sixty (160) were returned, out of which one hundred and thirty-five (135) were found usable for the study. The sample consisted of $55 \%$ female and $45 \%$ male. The participants were drawn from public secondary schools in Ilorin East, West, and South Local Government Area of Kwara State. The sample size of the study was considered adequate for applying the structural equation model which was used to test the relationship existing among the four constructs and to test the hypotheses formulated for the study. Prior to testing the hypotheses of the study, a Pearson product moment correlation coefficient was analyzed.

\section{Research Instrument and Measurement}

The items used for gathering the data of the study were operationalized. The instrument consists of twenty-three (23) items. The first part of the instrument consisted of demographic questions. The items used for measuring PU and PEOU were adapted from Davis (1989) study. Five (5) items each were used for measuring PU and PEOU. To measure self-efficacy, eight items developed by Compeau and Higgins (1995) were adopted without any modification. A survey format using a 7-pointscale (strongly disagree to strongly agree) was given as an option for the respondents to choose from. 
Table 1

Descriptive Statistics, Factor Loadings and Reliability

\begin{tabular}{|c|c|c|c|c|c|}
\hline Construct & ITEMS & Loading & $S D$ & $M$ & alpha \\
\hline \multirow[t]{4}{*}{ Self-Efficacy } & $\begin{array}{l}\text { 1: I could complete most task using Information } \\
\text { technology, if there is no one around to tell me what to } \\
\text { do }\end{array}$ & .65 & 1.53 & 4.06 & \\
\hline & 2:I feel comfortable using IT for teaching on my own & .69 & 1.33 & 4.40 & .80 \\
\hline & $\begin{array}{l}\text { 3.I could complete most teaching task with ICT with just } \\
\text { the built in help facility }\end{array}$ & .83 & 1.21 & 4.37 & \\
\hline & $\begin{array}{l}\text { 4.I feel confident to use IT software to deliver my } \\
\text { teaching presentation }\end{array}$ & .82 & 1.19 & 4,45 & \\
\hline \multirow{4}{*}{$\begin{array}{l}\text { Perceived } \\
\text { Usefulness }\end{array}$} & 1.Using IT will enhance my effectiveness in teaching & .61 & 1.27 & 4.79 & \\
\hline & 2.Using IT will meet my teaching/learning needs & .54 & 1.19 & 4.71 & .89 \\
\hline & 3.I find IT useful in my teaching & .56 & 1.25 & 4.79 & \\
\hline & 4.Using IT will improve the quality of my job & .74 & 1.22 & 4.83 & \\
\hline \multirow{5}{*}{$\begin{array}{l}\text { Perceived } \\
\text { Ease of Use }\end{array}$} & 1:Learning how to use IT is easy for me & .77 & 1.24 & 4.75 & \\
\hline & 2:find IT easy to do what I want to do & .75 & 1.18 & 4.88 & .90 \\
\hline & 3:Getting the information from the internet is easy & .71 & 1.25 & 4.84 & \\
\hline & 4: My interaction with IT facility is clear & .84 & 1.21 & 4,49 & \\
\hline & $\begin{array}{l}\text { 5:It would be easy for me to become skillful at using IT for } \\
\text { teaching }\end{array}$ & .75 & 1.35 & 4.62 & \\
\hline \multirow[t]{4}{*}{$\begin{array}{l}\text { Facilitating } \\
\text { Conditions }\end{array}$} & $\begin{array}{l}\text { 1. A central support is available to help in solving IT } \\
\text { related problem in my school }\end{array}$ & .70 & 1.46 & 3.66 & \\
\hline & $\begin{array}{l}\text { 2. The school management provided most of the } \\
\text { necessary IT resources in my school }\end{array}$ & .82 & 1.51 & 3.44 & . \\
\hline & $\begin{array}{l}\text { 3. Our school encourages us to use IT by providing us with } \\
\text { internet connection }\end{array}$ & .73 & 1.56 & 3.20 & .81 \\
\hline & $\begin{array}{l}\text { 4. Our school encourages us to use IT by giving us in- } \\
\text { house training }\end{array}$ & .72 & 1.67 & 3.29 & \\
\hline
\end{tabular}




\section{Results of Factor Analysis}

To determine the item adequacy and subject use for the study, a factor analysis was conducted to understand the dimensionality of the instrument of the study. In doing this, principal component analyses with varimax and Kaiser normalization rotation were performed, this enable us to test for the discriminant and convergent validity of the instrument. Table 1shows the validity of the items of the study. The factor loading, convergent validity and descriptive statistics used to measure the internal consistency of the items of the study were found adequate. The result indicated that the mean of the items range from 4.88 to 3.20 and the standard deviation ranges from 1.67 to 1.18. Also alpha analysis was carried out to determine the reliability of the instrument, all the alpha was above .80 indicating a strong reliability (Nunnally, 1978). Based on the aforementioned, the psychometric properties of the instrument are considered satisfactory for the present study.

\section{Pearson Product Moment Correlation Coefficient Result}

Correlation is concerned with the degree of strength in terms of relationship between two or more variables. The essence of conducting correlation is to know how two variables go together and covary (Neuman, 2003). In this study the correlation coefficient is conducted to see the relationship between all the variables used in the study. The correlation coefficient is a statistic used to explain the relationship between two variables. Pearson correlation coefficient $(r)$ can only take a value from -1 to +1 . This sign indicates whether there is positive or negative correlation, while the size of the correlation coefficient indicates the strength of the relationship. The nearer the size of the strength to (1) according to Pallant (2007) the stronger the correlation. Table 2 shows the analysis of the correlation coefficient of all the variables of the study.

Table 2

Correlation Coefficient of Self-Efficacy, Facilitating Condition, Perceived Ease of use and Perceived Usefulness

\begin{tabular}{lllll}
\hline & Self-efficacy & $\begin{array}{l}\text { Facilitating- } \\
\text { Condition }\end{array}$ & $\begin{array}{l}\text { Perceived } \\
\text { Ease of use }\end{array}$ & $\begin{array}{l}\text { Perceived } \\
\text { usefulness }\end{array}$ \\
\hline Self-efficacy & 1.00 & & & \\
Facilitating-Condition & $0.24^{* *}$ & 1.00 & & \\
Perceived Ease of use & $0.52^{* *}$ & $0.25^{* *}$ & 1.00 & 1.00 \\
Perceived usefulness & $0.58^{* *}$ & $0.16^{* *}$ & $0.77^{* *}$ & 1.00 \\
\hline
\end{tabular}

** Correlation is significant at the 0.01 level (2tailed) 
As indicated in Table 3, a positive correlation exists between all the variables of the study. The correlation between perceived ease of use and perceived usefulness stand to be the strongest in terms of strength, follow by perceived usefulness and self-efficacy, while correlation between facilitating condition and perceived usefulness shows a small correlation.

\section{Confirmatory Factor Analysis (CFA)}

In order to test the scale structured according to the factor analysis earlier conducted on the items, confirmatory factor analysis or CFA was conducted. The confirmatory factor analysis was done to validate all the indicators of the latent variables of the study. The essence of CFA in this study was to find out how well the indicators explain the variables as regards the use of IT for teaching. AMOS 20 was used for performing the analysis and test whether the data fitted the hypothesized measurement correlation. To test the goodness of fit indices in Structural Equation Modeling (SEM), the following indices were suggested by Arbuckle and Wothke (1995), Bollen (1998); and Byrne (2001). The results of confirmatory factor analysis and factor structure are given in Table 3.

Table 3

Acceptable Threshold for Goodness of fit

\begin{tabular}{lll}
\hline Index & Level of Acceptance & Comments \\
\hline RMSEA & RMSEA $<0.08$ & Range0.05-1.00acceptable \\
GFI & GFI $>0.90$ & GFI $0.90-1.00$ is a good fit \\
CFI & CFI $>0.90$ & CFI $0.90-1.00$ is a good fit \\
TLI & TLI $>0.90$ & TLI $0.90-1.00$ is a good fit \\
\hline
\end{tabular}




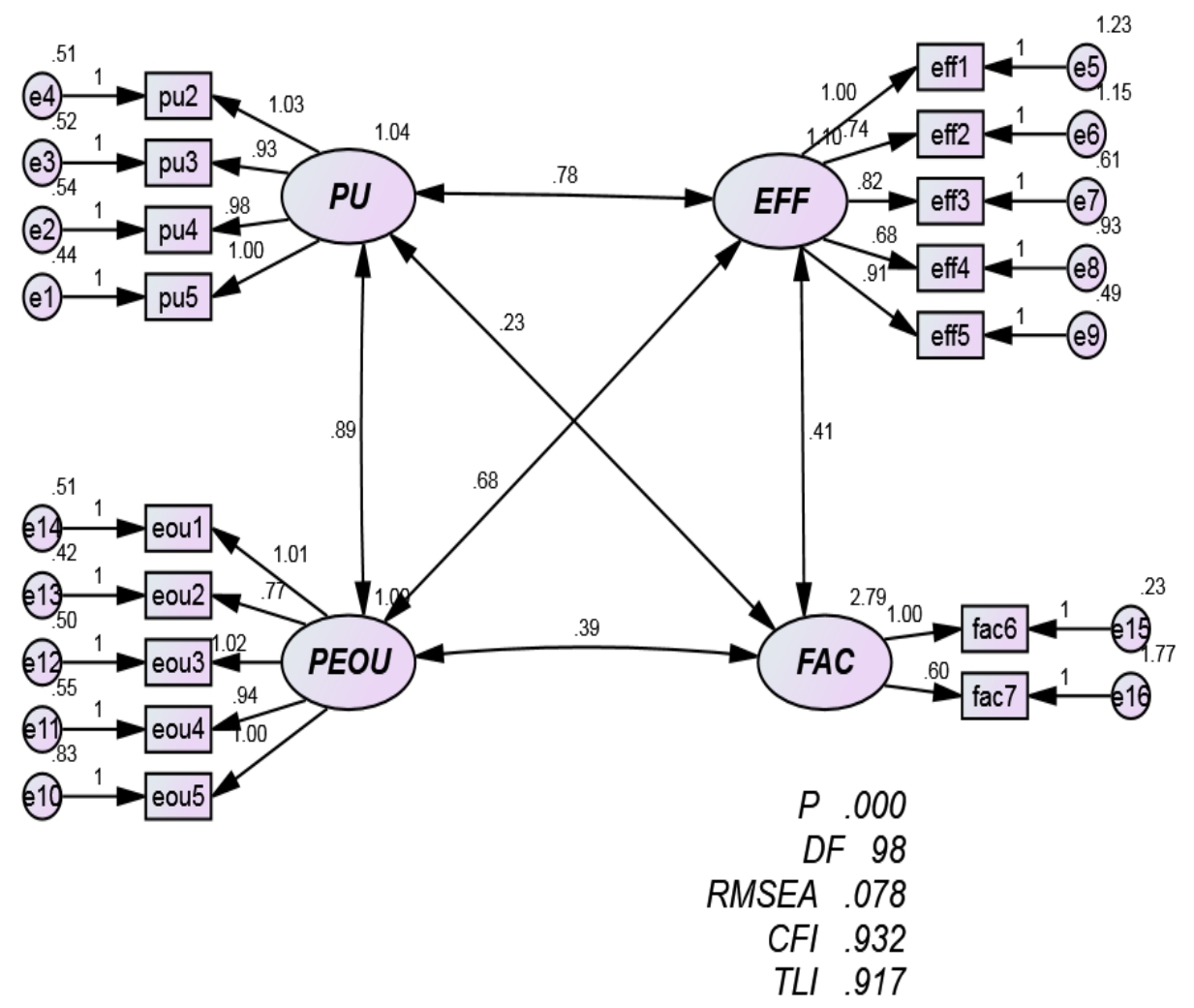

Figure2. Confirmatory factor analysis of Perceived usefulness, Perceived ease of use, Self-Efficacy, \& Facilitating Conditions 


\section{RESULTS OF HYPOTHESES TESTING}

Table 4 presents the results for strength of correlation between the constructs.

Table 4

Construct and Strength of Correlation

\begin{tabular}{|c|c|}
\hline Construct & Beta Value \\
\hline Perceived Usefulness $\longleftrightarrow$ Self Efficacy & $\beta=.78$ \\
\hline Perceived Usefulness $\longleftrightarrow$ Ease of Use & $\beta=.89$ \\
\hline Ease of Use $\longleftrightarrow$ Facilitating Condition & $\beta=.39$ \\
\hline Facilitating Condition $\longleftrightarrow$ Self Efficacy & $\beta=.41$ \\
\hline Ease of Use $\longleftrightarrow$ Self Efficacy & $\beta=.68$ \\
\hline Perceived Usefulness $\longleftrightarrow$ Facilitating Condition & $\beta=.23$ \\
\hline
\end{tabular}

Table 5

Influence of Gender on IT Use for Teaching: A Summary of Independent Sample t-Test Results ( $\mathrm{N}=123)$

\begin{tabular}{lllllll}
\hline Respondents & $\mathbf{N}$ & $\mathbf{d f}$ & $\boldsymbol{M}$ & $\boldsymbol{S D}$ & $\boldsymbol{t}$ & $\boldsymbol{p}$-value \\
\hline Gender & & & & & & \\
& & & & & & \\
\hline *Male & 56 & 121 & 14.33 & 3.93 & .23 & 0.82 \\
*Female & 67 & & 14.19 & 2.95 & & \\
\hline
\end{tabular}

*significant at $p<.05$

An independent sample $t$-test was conducted to increase the critical mass of the study through understanding if any difference existed in the teachers' use of IT for teaching vocational and technical subjects. The result in Table 5 revealed that there is no significant difference in the score of male $(M=14.34, S D=3.93)$ and female $(M=14.19$, $S D=2.95) ; t(121)=0.23, p=0.82$ (two-tailed). The magnitude of the difference is practically not significant (mean difference $=.14,95 \% \mathrm{cl}:-1.08$ to 1.37 .

Figure 2 shows the strength of the relationship between the constructs. The overall results of the statistical analyses demonstrated the adequacy of the correlation model. Chi-square, $\chi^{2}(\mathrm{df}=98)=168.798 ; p=0.000 ; \mathrm{RMSEA}=$ $.078 ; \mathrm{CFI}=.932 ; \mathrm{TLI}=.917$. The measurement model demonstrated a good-fit because the model passed the entire criterion. The interrelationships that exist among the constructs were observed based on the earlier stated hypotheses. 
H1: There will be a strong correlation between perceived usefulness and self-efficacy on the use of information technology by the teacher.

The finding of the relationship between perceived usefulness and computer self-efficacy was statistically significant $(\beta=.78)$. The correlation between these two construct shows a strong relationship; these validate the hypothesis earlier stated. Consequently, the hypothesis is supported.

H2: There will be a strong correlation between perceived usefulness and perceived ease of use on the use of information technology by the teacher

The finding of the relationship between perceived usefulness and perceived ease of use was statistically significant $(\beta=.89)$. The correlation between these two construct shows a strong relationship; these validate the hypothesis earlier stated. Consequently, the hypothesis is supported.

H3: There will be a strong correlation between perceived ease of use and facilitating condition on the use of information technology by the teacher

The finding of the relationship between perceived ease of use and facilitating condition was statistically significant $(\beta=.39)$. The correlation between these two construct shows a not too-strong relationship; these validate the hypothesis earlier stated. Consequently, the hypothesis is supported.

H4: There will be a strong correlation between facilitating conditions and self-efficacy on the use of information technology by the teacher

The finding of the relationship between facilitating conditions and computer self-efficacy was statistically significant $(\beta=.41)$. The correlation between these two construct shows a not too-strong relationship; these validate the hypothesis earlier stated. Consequently, the hypothesis is supported.

H5: There will be a strong correlation between perceived ease of use and self-efficacy on the use of information technology by the teacher

The finding of the relationship between perceived ease of use and computer self-efficacy was statistically significant $(\beta=0.68)$. The correlation between these two construct shows a not too-strong relationship; these validate the hypothesis earlier stated. Consequently, the hypothesis is supported.

H6: There will be a strong correlation between perceived usefulness and facilitating condition on the use of information technology by the teacher

The finding of the relationship between perceived usefulness and facilitating conditions was statistically significant $(\beta=0.23)$. The correlation between these two construct shows a not too strong relationship though the strength of relationship is practically significant; thus the hypothesis earlier stated is supported. 


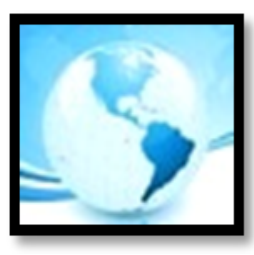

\section{DISCUSSION OF FINDINGS}

The implication of the study is that the findings have further contributed to understanding of the Technology Acceptance Model (TAM). The hypothesis stating that perceived usefulness will correlate with self-efficacy stands validated; this make the findings of the study incongruent with Agarwal and Karahanna (2000) who reported that teacher computer self- efficacy was an antecedent of PU and PEOU. Also, the correlation between perceived usefulness and perceived ease of use on acceptance to use IT in teaching, which was validated by this study, supported the earlier finding of Atiquil (2011) who reported a strong relationship between PU and PEOU on determinant of student adoption of online database as well as the earlier findings of Davis (1986) that revealed a strong correlation between PU and PEOU on acceptance of an information system. Furthermore, this study shows a not too strong correlation between perceived ease of use and facilitating condition, which was inconsistent with the finding of Tarcan et al. (2011) who reported a strong influence of facilitating condition on PEOU, though the hypothesis drawn was supported. In the same vein, facilitating condition was observed to have a strong correlation with computer self-efficacy. In fact, the correlation stands to be the one of the strongest in terms of the relationship existing between the two variables on IT acceptance for teaching. Another theoretical implication was that the study revealed a strong correlation between Perceived usefulness of IT and facilitating condition among the sample of the study. This finding supported that of Tarcan et al. (2011) who reported a positive influence of PU on facilitating condition.

\section{CONCLUSION}

The present study has further extended the scope of our understanding on factors that may influence acceptance of Information Technology in teaching and learning. In fact, the study has created a template for understanding the predictor of acceptance of Information Technology for teaching in the cultural environment of the study and by extension the Nigerian school system. The study was conducted to validate and extend the TAM by way of confirmatory factor analysis and enrich the existing literature on acceptance of innovations in education. The study has validated the users' acceptance indicator that will assist other researchers, government, school managers, and teachers in preventing problems associated with IT acceptance for teaching.

\section{REFERENCES}

Abedalaziz, N., Jamaludin, S., \& Leng, C. H. (2013).Measuring attitudes toward computer and internet usage among postgraduate students in Malaysia. The Turkish Online Journal of Educational Technology,12(2), 200-216.

Agarwal, R., \& Karahanna, E. (2000). Time flies when you're having fun: Cognitive absorption and beliefs about information technology uses. MIS Quarterly, 24(4), 665-694.

Al-Haderi, S. M. S. (2013). The effect of self-efficacy in the acceptance of information technology in the public sector. International Journal of Business and Social Science, 4(9), 188-198.

Arburkle, J.H.,\& Wothke, W (1995).AMOS 4.0 user's guide. IL: Small Waters 


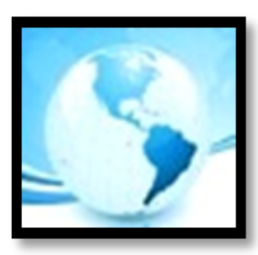

\section{MALAYSIAN ONLINE JOURNAL OF EDUCATIONAL MANAGEMENT (MOJEM)}

Atiquil-Islam, A.Y.M. (2011). Determinant of postgraduate students' adoption of the IIUM'S online database and their satisfaction in using it.(Unpublished Master thesis, Institute of Education, International Islamic University Malaysia).

Bandura, A (1986). Social foundations of thought and action: A social cognitive theory. Englewood Cliffs, NJ: Prentice Hall

Bollen, K. A. (1998). Structural Equations with latent variables New York, NY: Wiley

Byrne, B. M. (2001). Structural Equation Modeling with AMOS: Basic concepts, applications and programming. Mahwah, NJ: Erlbaum.

Compeau, D., \& Higgins, C.A. (1995).Computer self-efficacy: Development of a measure and initial test, MIS Quarterly,19(2),189-211.

Davis, F. D.(1986).A technology acceptance model for empirically testing new end-user information systems: Theory and results. (Doctoral dissertation, Sloan School of Management, MIT).

Davis, F. D. (1989). Perceived usefulness, perceive ease of use, and user acceptance of information technologies. MIS Quarterly, 13(3), 319-340.

Ertmer, P. A. (2005). Teacher pedagogical beliefs: The final frontier in our quest for technological integration? Educational Technology Research and Development, 53 (40, 1042-1629

Federal Republic of Nigeria (2004).National Policy on Education, Nigeria.Lagos: Nigeria Educational Research and Development Council (NERCD) Press.

Fishbein, M.,\& Ajzen, I. (1975).Belief, attitude, intention and behavior: An introduction to theory and research. Reading, MA: Addison-Wesley.

Groove, M. M., \& Zemmel, P. C (2005). Instructional technology adoption in higher education: an action research case study. International Journal of Instructional Media,27(1), 57-65.

Hair, J. F., Black, W. C., Babin, B. J., Anderson, R. E.,\& Tatham, R. L. (1998).Multivariate data analysis. Upper Saddle River, NJ: Pearson

Hendrickson, A. R., Masey, P. D., \& Cronan, T. P. (1993). On the test-retest reliability of perceived usefulness and perceived ease of use scales. MIS Quarterly,17(2), 227-230.

Li, N. (2002). Culture and gender aspect of student information searching behavior using the Internet: A two culture study of China and the United Kingdom. Doctoral thesis, Open University United Kingdom.

Ma, W. W., Anderson, R., \& Streith, K. (2005). Examining user acceptance of computer technology. An empirical study of student teachers'. Journal of Computer Assissted Learning, 21 (6), 387-395. 


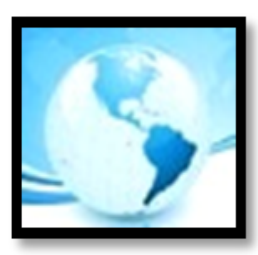

Myers, J. M., \& Halpin, R. (2002). Teacher attitude and use of multimedia technology in the classroom, constructivist based professional development training for school district. Journal of Computing in Teacher Education, 18 (4), 133-140.

Neuman, L.W. (2003). Social research methods: Qualitative \&quantitative approaches. (15 ${ }^{\text {th }}$ ed.) Boston, MA: Pearson Education.

Nunnally, J.C. (1978). Psychometric theory. New-York, NY: McGraw-Hill.

Pallant, J. (2007) SPSS survival manual: A step by step guide to data analysis using SPSS for window. Sydney, Australia: Allen \& Unwin.

Selwyn, N., Davies, L., \& Mercer, N. (2001). Promoting Mr 'chips' the construction of the teacher computer relationship on educational advertising. Teacher and Teacher Education Journal, 17, 3-14.

Selwyn, N. (2007). The use of Computer Technology in University teaching and learning: A critical perspective. Journal of Computer Assisted Learning,21 (2), 82-94.

Stylianou, A. C., \& Jackson, P. J.(2007). A comparative examination of individual difference and belief on technology usage: Gauging the role of IT. The Journal of Computer Information System, 47 (4), 11-18.

Tarcan, E.,Varol, E.S., Kantarci, K., \& Firlar, T. (2011).A study of Kazakh academician Information Technology acceptance. Retrieved from http://yayinlar.yeseri.edu.tr/files/article/570.pdf

Teo, T. (2008). Pre-service teachers' attitude towards computer use: A Singaporean survey. Australian Journal of Educational Technology,24(4), 413-424.

Teo, T. (2010).Explaining the intention to use technology among vocational users in education: An evaluation of the technology acceptance model (TAM) using structural equation modeling. International Journal of Instructional Media,37(4), 379-389.

Teo, T., \&Koh, J. H.L. (2010).Assessing the dimensionality of computer self-efficacy among pre-service teachers in Singapore: A structural equation modeling approach. International Journal of Education and Development Using Information and Communication Technology, 6(3), 7-18.

Venkateh, V., \& Davis, F. (1996). A model of the antecedent of perceived ease of use: Development and test. Decision Science, 27 (3), 451-481.

Venkatesh, V. (2000). Determinants of perceived ease of use: Integration control, intrinsic motivation, and emotion into the technology acceptance model. Information Systems Research,4(4), 342-365

Wu, W., Chang, H., \& Guo, C. (2008). An empirical assessment of science teachers' intention toward technology integration. Journal of Computers in Mathematics and Science Teaching, 27 (4), 499-520.

Yusuf, M. O. (2005). Information and communication technology and education: Analysis of the Nigerian national policy for information technology. International Education Journal,6 (3), 316-321. 


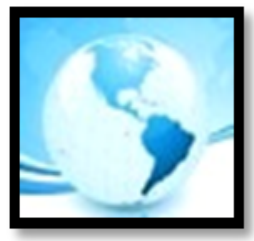

\section{MALAYSIAN ONLINE JOURNAL OF EDUCATIONAL MANAGEMENT \\ (MOJEM)}

Zhao, Y., \& Cziko, G. A. (2001). Teacher adoption of technology: A perceptual control theory perspective. Journal of Technology and Teacher Education, 9 (1), 5-30.

Zhao, Y., \& Frank, K. A. (2003). Factors affecting technology use in school: An ecological perspective. American Educational Research Journal, 40 (4), 817-840. 